\title{
Rational Religion: Economic Patterns in Old Testament Thought
}

Dr. Sigmund Wagner-Tsukamoto, School of Business, University of Leicester, saw14@le.ac.uk

\begin{abstract}
By tracing institutional and constitutional economic patterns to Old Testament thought, the thesis of a rational economic structure of the biblical text can be advanced and the actual nature and substance of religion can be conceptualised in economic terms. Here the paper questions the widespread assumption that religion will be radically different from modern ethics ('economics as ethics') in the tradition of the Scottish Enlightenment. In this regard, the paper specifically addresses the call for a concept of 'rational religion', as early on identified by Smith but contests the explicit claims of Smith or modern institutional economists like Buchanan that a concept of rational religion or 'economics as ethics' necessarily is separated from the Bible. An institutional economic theory of Old Testamentbased religion is proposed through a set of four theses. On the basis of these arguments, the paper outlines why Old Testament-based religion still has and could have a persistent and pervasive influence in contemporary, capitalist society.
\end{abstract}

\section{Key Words}

Rational religion; Old Testament; institutional / constitutional economics; economic pattern thesis; (rejection of) dualism thesis; new unitary thesis; pervasiveness / persistence of religion thesis; institutional economic theory of religion 


\title{
Rational Religion: Economic Patterns in Old Testament Thought ${ }^{1}$
}

\begin{abstract}
At present, no variant of religious economics is producing ideas that secular economists are likely to take seriously. ${ }^{2}$

[Where is] meta-analysis of economics and religion that will draw together economists and theologians [and biblical researchers in general] ... that is useful or persuasive to each ${ }^{3}$
\end{abstract}

\section{Introduction}

The paper connects to religious studies and Old Testament studies and projects them to constitutional and institutional economics. It aims to contribute to an institutional economic theory of Old Testament-based religion that addresses questions regarding the very nature and substance of religion, developing further my earlier research in this area. ${ }^{4} \mathrm{~A}$ key contention of the paper is that the Old Testament does not reflect, at least not in the first place, a legalistic religion (Gesetzesreligion) in the Mosaic tradition, as it is conventionally suggested. The Mosaic tradition here draws on the Decalogue and its derivative legal rules. Rather, the paper points at institutional and constitutional economic patterns as constitutive and foundational for Old Testament religion, with all the implications this has for challenging conventional understandings of what 'religion', 'secularization', 'modernity', or 'ancient ethics' could amount to.

Brennan and Waterman asked whether 'religion and economics were different' ${ }^{5}$; or lannaccone pointed at the importance of raising the question of the very 'substance of religion', especially so from economic vantage points ${ }^{6}$. However, the debates and answers

${ }^{1}$ The paper was presented at the annual conference of the European Public Choice Society (EPCS), University of Freiburg, Germany, 30 March - 2 April 2016. I gratefully acknowledge feedback and comments of referees and conference participants that helped to revise the paper.

${ }^{2}$ Timur Kuran, "Religious Economics and the Economics of Religion," Journal of Institutional and Theoretical Economics 150 (1994), 774.

${ }^{3}$ Kenneth G. Elzinga (1999), "Economics and Religion," in Religion and Economics: Normative Social Theory (ed. James M. Dean and Andrew M. C. Waterman; London: Kluwer, 1999), 139.

${ }^{4}$ Sigmund A. Wagner-Tsukamoto, The Economics of Paradise. On the Onset of Modernity in Antiquity (Basingstoke, UK: Palgrave Macmillan, 2014).

${ }^{5}$ H. Geoffrey Brennan and Andrew M. C. Waterman (Eds.), Economics and Religion: Are they Distinct? (Boston: Kluwer, 1994).

${ }^{6}$ Laurence R. Iannaccone, "Religious Practice: A Human Capital Approach," Journal for the Scientific Study of Religion 29 (1990), 312; Laurence R. Iannaccone, "Introduction to the Economics of Religion," Journal of Economic Literature 36(3) (1998), 1490. 
they delineated remained inconclusive. My argument suggests this was so because of a lack of focus on the foundational origin of Old Testament-based religion: the biblical text. They targeted process features of religion and of religious behaviour rather than the 'substance' of religion itself. The main argument of the paper is that any debate concerning religion and economics, and how such debate feeds through on questions regarding the very substance of religion, has to be centred on the biblical text itself, since it is this text that provides the foundational grounding of religion (Old Testament-based religion in the case of this paper).

The paper outlines how the Old Testament text can be modernised through reconstructing the text in institutional and constitutional economic terms (employing a nonhistoriographic, textual, narrative methodology in the first place). Reviewing my previous research in this area, economic patterns to biblical thought are traced. I connect to economics as it evolved with Smith and the Scottish Enlightenment, and as this tradition has been picked up and developed by contemporary constitutional and institutional economics. The paper argues for conceptual economic patterns in Old Testament thought, and advances this thesis on a comprehensive basis. This leads to a new unitary thesis: That not only faith as it is spiritually understood, can perceive or save the biblical text as an integrated, unified whole (the 'old' unitary thesis, as Nietzsche's nihilism implied this, by connecting to the historical-redactional school of biblical analysis) but that economic science can also yield a unitary thesis. In this way, the paper sets out a substantive understanding of 'rational religion', grounding it in the institutional and constitutional economic approach and thus specifying an understanding of 'economics as ethics' for the Old Testament text.

In consequence, the paper contests conceptual dualism: The idea that Old Testament ethics were radically different from modern 'economics as ethics', this concept of dualism having been thought to be constitutive for much of Enlightenment philosophy, from Spinoza and Hobbes onwards, at least up to Nietzsche ${ }^{7}$; for the Scottish Enlightenment too $^{8}$; and more recently, for economic sociology and economics ${ }^{9}$. What Buchanan termed

\footnotetext{
${ }^{7}$ For instance, Henning G. Reventlow, The Authority of the Bible and the Rise of the Modern World (London: SCM, 1984);Henning G. Reventlow, Epochen der Bibelauslegung: Von der Aufklärung bis zum 20. Jahrhundert, Vol. IV (Munich: C. H. Beck, 2001); A. Eugene Combs (1992), "Spinoza's Biblical Criticism and his Political Philosophy," in Liberal Democracy and the Bible (ed. Kim I. Parker; Lewiston/Queenston/Lampeter: Edwin Mellen Press, 1992), 73-99; Kim I. Parker, "Introduction: Reason, Revelation, and Liberal Democracy," in Liberal Democracy and the Bible (ed. Kim I. Parker; Lewiston / Queenston / Lampeter: Edwin Mellen Press, 1992), 1-17; Kim I. Parker, "Locke's Theologico-political Argument," in Liberal Democracy and the Bible (ed. Kim I. Parker; Lewiston / Queenston / Lampeter: Edwin Mellen Press, 1992), 101-127; Kim I. Parker, The Biblical Politics of John Locke (Waterloo, Ontario: Wilfrid Laurier University Press / Canadian Corporation for the Studies in Religion, 2004); Cameron J. Wybrow , "Hobbes as Interpreter of Biblical Political Thought," in Liberal Democracy and the Bible (ed. Kim I. Parker; Lewiston / Queenston / Lampeter: Edwin Mellen Press, 1992), 39-71.

${ }^{8}$ See Adam Smith, An Inquiry into the Nature and Causes of the Wealth of Nations, 2 Volumes (Oxford: Clarendon., 1976); Peter Minowitz, Profits, Priests and Princes. Adam Smith's Emancipation of Economics from Politics and Religion (Stanford: Stanford University Press, 1993).

${ }^{9}$ See Max Weber, Ancient Judaism (London: Allen and Unwin / Free Press, 1952); Max Weber, General Economic History (Transl. Frank H. Knight, New York: Colliers Books, 1961); Max Weber, The Protestant Ethic and the Spirit of Capitalism (London: Routledge, 2001).'Even' for James
} 
the 'moral precepts approach'10, which he divided from constitutional economics, may reflect a considerable economic rational religious dimension, thereby feeding into and aligning itself with Buchanan-type constitutional economics. I return to this issue in the paper when I comment on North's and Williamson's questions on religion. ${ }^{11}$

Following on, section three of the paper addresses a widely debated question in institutional economic debate on religion ${ }^{12}$ : why religion has had over time, at least since biblical times and up to now, a pervasive and persistent influence in numerous societies, even in societies which many may consider as being secular ${ }^{13}$. In this regard, the paper argues for an undergirding effect which rational, economically patterned religion develops in capitalist societies, specifically regarding the way in which such societies more formally set out constitutional and institutional economic order.

A final section of the paper offers conclusions on how the various theses developed in the paper interlink; how they, once interconnected, form a theory on rational religion.

On a brief methodological note, the textual reading strategy I employ when analysing the Old Testament text connects to textual criticism, text-immanent reading, and non-historiographic narratology, more broadly conceived. The Old Testament is interpreted as prose fiction, as I have outlined this methodology in my previous research. Since the mid1970s, this text-critical approach has made considerable inroads into biblical, theological and religious research. ${ }^{14}$

M. Buchanan, The Limits of Liberty. Between Anarchy and Leviathan (Chicago, Ill.: University of Chicago Press, 1975), 117, 147-148 as reviewed by Sigmund A. Wagner-Tsukamoto, "Out of a Slave Contract. The Analysis of Pre-Hobbesian Anarchists in the Old Testament," Constitutional Political Economy 21 (2010): 288-307.

${ }^{10}$ Buchanan, Limits of Liberty, 117.

${ }^{11}$ Douglas C. North, "Institutions," Journal of Economic Perspectives 5(1) (1991), 111; Oliver E. Williamson, "The New Institutional Economics: Taking Stock, Looking Ahead," Journal of Economic Literature 38 (2000), 596.

${ }^{12}$ For instance, North, "Institutions"; Williamson, "New Institutional Economics".

${ }^{13}$ Regarding this latter suggestion on non-secularization, see Reventlow, Authority of Bible, 411; Laurence R. lannaccone, "Progress in the Economics of Religion," Journal of Institutional and Theoretical Economics 150 (1994), 738, 741, 741; Ronald Inglehart and Wayne E. Baker, "Modernization, Cultural Change, and the Persistence of Traditional Values," American Sociological Review 65 (2000): 19-51; Jacques Berlinerblau, The Secular Bible: Why Nonbelievers Must Take Religion Seriously (Cambridge: Cambridge University Press, 2005); Rachel M. McCleary and Robert Barro, "Religion and Political Economy in an International Panel," Journal for the Scientific Study of Religion 45 (2006): 149-175.

${ }^{14}$ Some key methodological contributors are Jan P. Fokkelman, Narrative Art in Genesis: Specimens of Stylistic and Structural Analysis (Amsterdam: Van Gorcum, 1975); David J. Clines, "The Theme of the Pentateuch," JSOTSup 10 (1978): 1-152; David J. Clines. (1998), "Methods in Old Testament Study," in Beginning Old Testament Study (ed. John W. Rogerson; London: SPCK, 1998), 25-48; Robert Alter, The Art of Biblical Narrative (New York: Basic Books, 1981); David J. Clines and J. Cheryl Exum. (1993), "The New Literary Criticism," in The New Literary Criticism and the Hebrew Bible (ed. J. Cheryl Exum and David J. A. Clines; Sheffield: JSOT Press, 1993), 11-25; Gerrie Snyman, "Narrative Rationality, Morality and Readers' Identification," Old Testament Essays 15(1) (2002): 


\section{The Call for Rational Religion}

So, '... why bother with biblical studies now?'15 The present paper develops an answer to this question by pointing out that the Old Testament holds a more than nascent theory on institutional and constitutional economic structure and order, in effect predating many of the conceptual advances of the Scottish Enlightenment and more recent advances in institutional and constitutional economics. Ultimately, the paper ventures to set out a rational - economic - theory of Old Testament-based religion in order to argue for the continuing contemporary relevance of studying the Old Testament, also (and possibly even more so), for normative, justificatory reasons and not merely conceptual, theory foundational ones. In order to develop this project, I first picked up the call for rational religion.

\section{Smith's Call for Rational Religion}

There are at least two important aspects to Smith's call for 'rational religion' ${ }^{16}$, which I subsequently assessed in turn. One is that he raised the call at all; here, I recast and conceptually specify Smith's call in his very own economic terms: interpreting 'his' economics as a new, systemic ethics that provides for the substantively conceptual backbone of rational, biblical religion. The other important aspect of Smith's call for rational religion is his claim that rational religion by conceptual necessity had to be freed from the Bible. I critically examine this latter claim - and reject it, by reconstructing contemporary constitutional and institutional economics, which arose out of Smith's own studies, for the biblical text.

Smith argued that 'rational religion' is characterised by being free from 'every absurdity, imposture, fanaticism, superstition' and by being grounded in 'positive law':

The teachers of each little [religious] sect, finding themselves almost alone [i.e. in strong competition with other religions], ... might in time probably reduce the doctrine of the greater part of them to that pure and rational religion, free from every absurdity, imposture or fanaticism; but such ... positive law has perhaps never yet been established, and probably never will be established in any country: because with regard to religion, positive law always has been, and probably always will be, more or less influenced by popular superstition and enthusiasm. ${ }^{17}$

179-199; Mieke Bal, Narratology: Introduction to the Theory of Narrative (Toronto: University of Toronto Press, 2009).

${ }^{15}$ Jaco Gericke, The Hebrew Bible and Philosophy of Religion (Atlanta: SBL; 2012), 527, emphasis as in original.

${ }^{16}$ Smith, Wealth of Nations, 798-793.

${ }^{17}$ Smith, Wealth of Nations, 793. 
There are various insights implied by this statement of Smith: That 'rational religion' would only emerge over time through a competitive process of different religions competing for believers ${ }^{18}$, and that this process would drive the elimination of 'irrational' content from religion, ultimately leading to the 'true, rational religion' that is grounded in 'positive law'.

The kind of 'positive law' Smith had in mind here is some kind of ethical rationalism his recommendation '...the study of science and philosophy' ${ }^{19}$. Utilitarianism or Kantianism can be seen as early potential answers to this call from Smith - the way he expected answers to be set out. What he did not see was that 'rational religion' and the kind of 'positive law' that may structure it could be set out in the terms of his own economic theory, with his economics being interpreted as a 'new' kind of ethics.

Since I follow institutional and constitutional economic lines of reconstructing rational religion with a view to the Old Testament text, first, it had to be demonstrated that Smith's economics reflect both institutional and constitutional economics. This is comparatively straightforward: Viner's, Reisman's or Khalil's studies for instance are instructive ${ }^{20}$, as is contemporary institutional and constitutional economic research, which connects to Smith (very explicitly so in Buchanan's case).

Second, it has to be shown that contemporary institutional and constitutional economics reflect 'positive law' about morality, i.e. that it can be conceived as 'ethics'. The key point here is that economics from Smith onwards reflects a new kind of ethics; an 'economics as ethics': that is systemically rational and ethical, yet disconnected from behavioural ethical rationalism such as Kantianism, or a behavioural, spiritual and personal understanding of religion. ${ }^{21}$ Research at the intersection of economics and ethics has generally made this point that Smith's economics initiated systemic ethics and that it continues traditional, behavioural ethics by different means ${ }^{22}$. Smith himself developed and

${ }^{18}$ Garry M. Anderson, "Mr. Smith and the Preachers: The Economics of Religion in the Wealth of Nations", Journal of Political Economy 96 (1988), 1073-1074; Iannaccone, "Progress", 740-741.

${ }^{19}$ Smith, Wealth of Nations, 796.

${ }^{20}$ Jacob Viner, "Adam Smith and Laissez Faire," Journal of Political Economy 35 (1927): 198-232; David A. Reisman, "Adam Smith on Market and State," Journal of Institutional and Theoretical Economics 154 (1998): 357-384; Elias L. Khalil, “Is Adam Smith a Liberal?” Journal of Institutional and Theoretical Economics 158.4 (2002): 664-695.

${ }^{21}$ This could be found, in certain respects, in Smith's Theory of Moral Sentiments too; see also Sigmund A. Wagner-Tsukamoto, "The Adam Smith Problem Revisited: A Methodological Resolution," Journal des Economistes et des Etudes Humaines 19 (2013): 63-99.

${ }^{22}$ See James M. Buchanan, Economics: Between Predictive Science and Moral Philosophy (College Station: Texas A\&M University Press, 1987); James M. Buchanan, The Economics and the Ethics of Constitutional Order (Ann Arbor, MI: University of Michigan Press, 1991); Karl Homann, "Sinn und Grenze der ökonomischen Methode in der Wirtschaftsethik," Volkswirtschaftliche Schriften 478 (1997): 1-42; Karl Homann (1999), "Zur Grundlegung einer modernen Gesellschaftsand Sozialpolitik: Das Problem der Sozialen Ordnung," in Soziale Marktwirtschaft im nächsten Jahrtausend (ed. Ulrich Blum, Werner Esswein, Erich Greipl, Hannjörg Hereth and Stefan Müller; Stuttgart, Germany: Schäffer-Poeschel, 1999) , 119-148; Paul Heyne, 'Are Economists Basically Immoral?' and other Essays on Economics, Ethics, and Religion (ed. H. Geoffrey Brennan and Andrew M. C. Waterman, Indianapolis: Liberty Fund, 2008); Stefano Gorini (2009), “An Economist's Plaidoyer for a Secular Ethics: The Moral Foundation and Social Role of Critical Rationalism," in The Economics 
realised this aspect of economics as systemic ethics inadequately: Although his mutual gains programme on the 'wealth of nations' sets out a systemic ethics in his writings - that all parties involved in an interaction need to be better off as a result of the interaction - his specific programme of rational religion remained aloof, underdeveloped and separated from a systemic ethics programme. This is clearly seen by the way he did not follow up 'positive law' of rational religion with regard to a systemic ethics perspective of economics (i.e. regarding economic institutions).

This brief discussion should suffice to indicate that Smithsonian economics do reflect and are connected to contemporary institutional and constitutional economics, and that Smithsonian economics do yield ethics. Taken together, 'positive law' of 'rational religion' can be set out in Smith's own economic terms, projected to contemporary institutional and constitutional economics, and understood as systemic ethics.

The second aspect of Smith's call for rational religion related to his claim that rational religion needed to be freed from the Bible. His writings were critical of biblical religion and at times an atheistic or secular stance has been suggested for the Wealth of Nations. ${ }^{23}$ Minowitz here confirms that Smith's ideal vision of 'true, rational religion' not only mirrored 'positive law' (of some kind of ethical rationalism, largely behaviourally interpreted by Smith, as discussed above) but also aimed to free religion from the Bible, diagnosing 'biblical irreligiosity' and the 'rejection of biblical religions' for Smith ${ }^{24}$. Smith brandished in this regard 'tenets' and 'doctrine' of biblical religion:

[The] interested diligence of the clergy is what every wise legislator will study to prevent; because, in every religion except the true, it is highly pernicious, and it has a natural tendency to pervert the true [rational religion], by infusing into it a strong mixture of superstition, folly, and delusion. ... No regard will be paid to truth, morals, or decency in the doctrines inculcated. Every tenet will be adopted that best suits the disorderly affections of the human frame. ${ }^{25}$

Smith did not see that biblical canon ('tenets', 'doctrine') and the way it is interpreted, can itself provide the very basis of 'rational religion' and 'positive law'. In this respect, the paper draws on canonical criticism in the vein of the institutional and constitutional economic reconstruction of Old Testament stories to set out an economic concept of rational religion and its 'positive laws'. A rational system of belief emerges which leaves the biblical text as such unchallenged (at its 'contents' level), but not so in terms of hypotheses, deductions, motifs and themes that are attributed to the text. Then, faith and religion can be rationally justified too, and this works through grounding rational religion in the Bible and in biblical religion, against Smith's expectations. An underlying assumption is here that that the biblical text carries religious significance, however 'the religious' may be interpreted (in a traditional, spiritual way; or alternatively, in a rational economic one).

of Ethics and the Ethics of Economics: Values, Markets and the State (ed. H. Geoffrey Brennan and Giuseppe Eusepi; Cheltenham: Edward Elgar), 32-50).

${ }^{23}$ Minowitz, Profits, 154-156, 166.

${ }^{24}$ Minowitz, Profits, 166, 188; for this 'rejection' of Smith, see Smith, Wealth of Nations, 802-806; also Minowitz, Profits, 154-156, 235.

${ }^{25}$ Smith, Wealth of Nations, 791. 


\section{Contemporary Re-statements of Smith's Call}

Contemporary research, as already touched upon, has explicitly and implicitly returned to Smith's call for rational religion, and interestingly has succeeded in reproducing either one or other of his misconceptions regarding rational religion or sometimes both: namely (a) that a rational, modern approach to religion had to follow some kind of ethical rationalism, e.g. Kantianism, rather than the systemic ethics approach of economics (i.e. his 'own' economics); and/or (b) that a rational, modern approach to religion needed to be freed from the Bible, 'rational religion' being split from biblical religion.

I am not reviewing at this point the project of theological economics, as it has been directed at Smith too ${ }^{26}$. These reconstruction efforts target a religious economics, aiming to conceptually infuse economics with theology, rather than an economics of religion.

Nevertheless, some of the claims of religious economics are worthwhile pointing out: claims such as that Smithsonian economics overturned from the $18^{\text {th }}$ century onwards '...

traditional ways of life, ... [and] ancient social, political, and religious compromises ${ }^{\prime 27}$, or that Enlightenment philosophy secularised previously 'religious' life ${ }^{28}$. The reconstruction of rational religion through institutional and constitutional economics and the grounding of this project in the biblical text challenge these perceptions, and with it the dualism thesis that ancient ethics were radically different from modern ethics. This also sheds critical light on the clear-cut differentiation of religion from secularization, as raised by Stuckrad and especially his suggestions on the 'scientification' of religion and the concept of a 'Vernunftreligion'29 - ideas which the current paper can connect to but turns in economic terms.

In my view there is little doubt that Smith's call for rational religion related to the project of an economics of religion. Therefore, I mainly review literature from this tradition, which in one way or another pursues a scientific (economic) or philosophical, enlightened approach regarding religious research.

Reventlow exemplarily identified the supposed disengagement of 'modern,' expectedly 'rational' political philosophy and political economy from the Bible and from biblical religious thought. He argued that from Hobbes and Spinoza onwards:

The Bible lost its significance for philosophical thought and for the theoretical constitutional foundations of political ideals, and ethical rationalism (with a new

\footnotetext{
${ }^{26}$ See M. Douglas Meeks, God the Economist: The Doctrine of God and Political Economy (Minneapolis, MN: Fortress Press, 1989); Lisa Hill, "The Hidden Theology of Adam Smith," European Journal of the History of Economic Thought 8 (2001): 1-29; Duncan K. Foley, Adam's Fallacy: A Guide to Economic Theology (Cambridge, MA: Belknap / Harvard University Press, 2006).

${ }^{27}$ Foley, Adam's Fallacy, 227.

${ }^{28}$ Kuran, "Religious Economics", 770.

${ }^{29}$ Kocku von Stuckrad, "Secular Religion: A Discourse-historical Approach to Religion in Contemporary Western Europe", Journal of Contemporary Religion 28 (2013), 6-7, 9.
} 
foundation in Kant's critique) proved to be one of the forces shaping the modern period, which only now can really be said to have begun. ${ }^{30}$

Reventlow stakes two claims: First, modernity is thought to have split political economy and political philosophy from the Bible; and second, ethical rationalism, especially Kantianism, is thought to have become the substitute for biblical religion. No vision of a 'rational religion' that is grounded in the Bible is evident. Rather, the dualism thesis is held up to pronounce that biblical religion and biblical ethics are radically different from modern, Enlightenment ethics.

Minowitz, as initially reviewed above, similarly divides: Smith's Wealth of Nations from earlier periods, pointing out that Smith emancipated social thought that then saw the emergence and separation of economics from (biblical) religion and religious thought ${ }^{31}$; for instance, Minowitz does not question that a concept of 'rational religion' as favoured by Smith with a view to ethical rationalism, could be developed differently, namely by staging Smith's own economics as ethics on the biblical text and thus on biblical religious thought. Lütge's assessment compares to Minowitz in certain respects, when he differentiated 'traditional ethics' and supposedly 'pre-modern' society from economic ethics and modern society ${ }^{32}$; only Smith is seen as the 'ancestor of [modern] economic ethics'. Again, a critical question is what are the ancestry implications of reconstructing rational religion through economics and the Old Testament text?

Buber came to the same conclusion that '... the modern Occident rests upon the sanctioned duality of politics and religion', that political economy and religion - even 'rational religion'? ${ }^{33}$, I would ask at this point- were theoretically and normatively apart. Weber implied this too, arguing that biblical religion and biblical stories - focusing on the Paradise story, at this point - were not 'rational-ethical' ${ }^{34}$. Hill claimed '... the late-modern [from the $18^{\text {th }}$ century onwards] separation of the disciplines of economics, moral philosophy and theology' 35 . Buchanan, Foley, and Mueller implied the same ${ }^{36}$; or as Brennan and Waterman put this: '... traditional economics and Christianity offer rival accounts of human rationality' ${ }^{37}$. Can we really accept comparable points of views such as Bruce's,

${ }^{30}$ Reventlow, Authority of Bible, 414.

${ }^{31}$ See Minowitz, Profits.

32 See Christoph Lütge, "Economic Ethics, Business Ethics and the Idea of Mutual Advantages," Business Ethics. A European Review 14(2) (2005), 108, 111.

${ }^{33}$ Martin Buber, Pointing the Way: Collected Essays (London: Routledge and Kegan, 1957), 135.

${ }^{34}$ Weber, Ancient Judaism, 219.

${ }^{35}$ Hill, “Adam Smith”, 22.

36 Buchanan, Limits of Liberty, 117, 147-148; Foley, Adam's Fallacy, 1, 215; Dennis C. Mueller, Reason, Religion, and Democracy (Cambridge: Cambridge University Press, 2009).

${ }^{37}$ H. Geoffrey Brennan and Andrew M. C. Waterman, "Summary if not Conclusions", in Economics and Religion: Are They Distinct? (ed. H. Geoffrey Brennan and Andrew M. C. Waterman; Boston: Kluwer, 1994), 253. 
Bryant's, Saler's, Heyne's, Gorini's or Wishloff's, that modern i.e. Smithsonian capitalist economics cannot illuminate religion in its very nature and substance? ${ }^{38}$

In the next section, I set out to critically question the dualism thesis. I contend that some kind of ethical rationalism, which was (a) different from 'economics as systemic ethics' and (b) which distanced itself from the Bible, provided the more viable conceptual route for setting out a concept of 'rational religion'. To question the dualism thesis, the paper first searches for 'rational' economic patterns to biblical thought, tracing in the Smithsonian tradition economics as systemic ethics in the Old Testament text (before the dualism thesis is more directly addressed).

\section{Economic Patterns in Biblical Thought: A Theory of Rational Religion}

What is religion? I pursue this potentially complex question from an economic point of view, but not merely a viewpoint of economic research in the sense of 'moral rules of religion' acting as a provider of some kind of transaction capital or stability generating capital for society, at least not in the first instance. In this latter tradition, economic process features of religion have been researched, for instance, by Anderson and Tollison ${ }^{39}$. Equally, I do not take moral rules of society as some kind of unquestioned behavioural 'given' in my analysis. This latter understanding may surface at times 'even' in Buchanan's analysis when he talks about 'moral community', or about the 'moral precepts' approach ${ }^{40}$, or when institutional and constitutional economic research has put forward proposals on 'civic religion' 41 .

My interest in the economics of religion focuses on the very substance and nature of Old Testament-based religion. lannaccone reminded researchers to urgently address this question ${ }^{42}$. In a similar vein, Brams called upon research to 'rationally justify faith'43. Or, Moore and Sherwood argued regarding the nature of religion to fundamentally re-think

${ }^{38}$ Steve Bruce, Choice and Religion: A Critique of Rational Choice Theory (Oxford: Oxford University Press, 1999); Joseph M. Bryant, "Cost-benefit Accounting and the Piety Business: Is Homo Religiosus, at Bottom, a Homo Economicus?" MTSR 12 (2000), 547; Benson Saler, "Towards a Realistic and Relevant 'Science of Religion'," MTSR 16 (2004), 213; Heyne, Are Economists Immoral?, 196-8, 215-6; Gorini, "Secular Ethics", 34-35; Jim Wishloff, "The Hard Truths of the Easy Essays: The Crisis of Modernity and the Social Vision of Peter Maurin," Journal of Religion and Business Ethics 2(2, Article 2) (2013), especially 5-9.

${ }^{39}$ Garry M. Anderson and Robert D. Tollison, "Morality and Monopoly: The Constitutional Political Economy of Religious Rules", Cato Journal 12(2) (1992): 373-392.

${ }^{40}$ Buchanan, Economics Predictive Science, 289-300; see also Buchanan, Limits of Liberty, 117.

${ }^{41}$ Bruno S. Frey, "A Constitution for Knaves Crowds out Civic Virtues," Economic Journal 107 (1997): 1043-1053; Roger D. Congleton, "The Contractarian Constitutional Political Economy of James Buchanan," Constitutional Political Economy 25 (2014), 52; Alan Hamlin, "Reasoning about Rules," Constitutional Political Economy 25 (2014), 78, 84-85.

42 Iannaccone, "Religious Practice", 312; lannaccone, "Introduction", 1490.

${ }^{43}$ Steven J. Brams, Game Theory and the Humanities: Bridging Two Worlds (Cambridge, Mass.: MIT Press, 2011), 70. 
religion and to engage in '... meta-critical analysis of our disciplinary pasts that would radically dismantle the default categories in which we operate as biblical scholars, and thereby enable modes of biblical analysis that cannot at present easily be envisioned. ... We need to find religion. ${ }^{44}$

I take up these contemporary calls in their primal nature; how religion in its very essence can live up to Smith's call for rational religion, substantively answering this call through the reconstruction of biblical text by means of economics as ethics. In this way, I answer Smith's call and similar contemporary re-statements ${ }^{45}$. In its substantive outcomes, this yields a concept of rational religion through the economic pattern thesis of biblical thought.

\section{Pursuing the New Unitary Thesis: Biblical Economics as Ethics}

Brennan and Waterman asked whether economics and religion were different ${ }^{46}$. My key argument is here that for the biblical text has to be focused on and be reconstructed in the conceptual and ethical terms of economics as ethics, thus illuminating the nature of religion. In this way, I identified economic patterns to biblical thought, drawing on institutional and constitutional economic theory; and reviewing my previous research in this area to distinguish five key conceptual features; three being theoretical and practical/normative concepts, and two being heuristic, methodological ones: (1a) a model of interactions over capital exchange; (1b) the concept of economic institutions to stir capital exchange; (1c) the normative-ethical goal of mutuality of gains as interaction outcome (to be reached through the situational intervention with economic institutions); and the heuristic ones comprise (2a) a model of rational, self-interested choice (homo economicus); and (2b) a model of dilemmatic interest conflicts (such as the prisoner's dilemma concept).

The thesis of economic patterns is staked in a comprehensive manner: that economic patterns do not show up merely as singular or unimportant instances in the biblical text; rather they serve to illuminate the text inclusively and in its totality, particularly for the best-known and oldest stories of the Old Testament, i.e. the Torah. A unitary thesis is advanced for the biblical text. My previous research here has spanned from Genesis to Kings. On this foundation, by coupling the economic pattern thesis with the unitary thesis, I subsequently challenge the dualism thesis.

The first theoretical element I trace is the idea of capital exchange, that the interacting agents described in the biblical text contribute capital to an exchange interaction and expect capital distributions in return. From the very outset of biblical storytelling capital exchange is apparent: in the Paradise story ${ }^{47}$. Capital exchange remains a big issue in the

${ }^{44}$ Stephen D. Moore and Yvonne Sherwood, The Invention of the Biblical Scholar: A Critical Manifesto (Minneapolis: Fortress Press, 2011), 131.

45 Iannaccone, "Introduction", 1490; Brams, Game Theory, 70; Moore and Sherwood, Biblical Scholar, 131, as quoted above.

${ }^{46}$ Brennan and Waterman, Economics and Religion; H. Geoffrey Brennan and Andrew M. C. Waterman, "Introduction: Economics and Religion?," in Economics and Religion: Are They Distinct? (ed. H. Geoffrey Brennan and Andrew M. C. Waterman; Boston: Kluwer, 1994), 3 -15; Brennan and Waterman, "Summary".

${ }^{47}$ Sigmund A. Wagner-Tsukamoto, "Economics of Genesis. On the Institutional Economic Deciphering and Reconstruction of the Legends of Genesis," Journal of Interdisciplinary Economics 12 (2001), 264, 267-269; Sigmund A. Wagner-Tsukamoto, Is God an Economist? An Institutional 
Jacob stories ${ }^{48}$; in the Joseph stories ${ }^{49}$; in the exodus stories ${ }^{50}$; and in the stories of the settlement phase ${ }^{51}$. The tracing of a model of capital exchange is significant since it is a central tenet of constitutional and institutional economics to conceptualise trade in interactions between two parties ${ }^{52}$ - and how contest in capital exchange can arise (as I specify this below with respect to the homo economicus and the idea of a dilemma structure).

Economic institutions are the second key theoretical component. Taken from a constitutional and institutional economic point of view, interactions over capital exchange are stirred through economic institutions: through the situational, economic context of governance structures. Such structures, both at the constitutional and post-constitutional level, are approached as 'incentive structures': The influence of incentive signals, as emitted by economic institutions, is studied in order to understand any (whether desirable or

Economic Reconstruction of the Old Testament (Basingstoke, UK: Palgrave Macmillan, 2009), 50-56; Sigmund A. Wagner-Tsukamoto, "The Paradise Story: A Constitutional Economic Reconstruction," JSOT 34(2) (2009): 152-154, 158-160; Wagner-Tsukamoto, "Slave Contract", 293-295; Sigmund A. Wagner-Tsukamoto, "The Tree of Life: Banned or not Banned? A Rational Choice Interpretation," SJOT 26(1) (2012): 113, 118; Sigmund A. Wagner-Tsukamoto, "After the Theft: Natural Distribution States and Prisoner's Dilemmas in the Paradise Story," OTE 25(3) (2012), 716-731; WagnerTsukamoto, Economics of Paradise, especially chapter 2.

${ }^{48}$ Wagner-Tsukamoto, "Economics of Genesis", 265, 275-276; Wagner-Tsukamoto, God an Economist?, 84, 86-89, 96; Wagner-Tsukamoto, "Slave Contract", 297; Wagner-Tsukamoto, "Questioning the Weber Thesis: Capitalist Ethics and the Hebrew Bible?," Sociology Mind 2(1) (2012), 4; Sigmund A. Wagner-Tsukamoto, "Homo Economicus and the Stories of Jacob: On the Methodological Relevance of Rational Choice Theory for Studying the Hebrew Bible," MTSR 25 (2013), 87.

${ }^{49}$ Sigmund A. Wagner-Tsukamoto, "An Economic Reading of the Exodus: On the Institutional Economic Reconstruction of Biblical Cooperation Failures," SJOT 22(1) (2008), 126-127; Wagner-Tsukamoto, God an Economist?, 123-128; Wagner-Tsukamoto, "Slave Contract", 302-303; Wagner-Tsukamoto, "Weber Thesis", 5; S Sigmund A. Wagner-Tsukamoto, "The Genesis of Cooperation in the Stories of Joseph: A Constitutional and Institutional Economic Reconstruction," Working and Research Paper, School of Management, University of Leicester, Leicester Research Archive: http://hdl.handle.net/2381/27684.; publication forthcoming in SJOT, 16, 19-20, 25; Sigmund A. Wagner-Tsukamoto, "The City Metaphor and Pluralism in Genesis: Institutional Economics Between Pre-modern and Modern Urbanism," Working and Research Paper, School of Management, University of Leicester (2013) Leicester Research Archive:

http://hdl.handle.net/2381/27894, 21-22;

${ }^{50}$ Wagner-Tsukamoto, "Exodus", 119-121; Wagner-Tsukamoto, God an Economist?, 142$147,150-154$.

${ }^{51}$ Wagner-Tsukamoto, God an Economist?, 194-195; Sigmund A. Wagner-Tsukamoto, "State Formation in the Old Testament: An Institutional Economic Perspective," JSOT 37(4) (2013), 402-418.

52 James M. Buchanan, “What Should Economists Do?,” Southern Economic Journal 30(3) (1964): 213-222; Victor J. Vanberg, Rules and Choice in Economics (London: Routledge, 1994); Alain Marciano, "Buchanan's Constitutional Political Economy: Exchange vs. Choice in Economics and in Politics," Constitutional Political Economy 20 (2009): 42-56. 
undesirable) outcomes of capital exchange (What 'desirability' could ethically mean is discussed below with a view to 'mutual gains'). Desirable, cooperative outcomes reflect that economic institutions 'equilibrate ${ }^{53}$ potentially conflicting interests of interaction choice makers, resolving conflict by means of organising incentive structures. So, can we trace economic institutions as a key situational regulative of capital exchange in biblical stories?

Economic institutions appear in biblical stories as work allocation schemes, property rights structures, tax systems, organisational / bureaucratic hierarchy, structures of constitutional contract, etc.: In the Paradise story ${ }^{54}$; in the Jacob stories ${ }^{55}$; in the Joseph stories $^{56}$; in the exodus stories ${ }^{57}$; and in the stories of the settlement ${ }^{58}$. These stories can be studied for economic institutions in order to understand why sometimes capital exchange succeeded and was sustained, while at other times it disastrously disintegrated - because, such is my argument, economic institutions were at times 'incentive-compatible' while at other times they were not.

Third, in practical-normative terms it is important to set out the idea that economic reconstruction of the biblical text yields some kind of ethical rationalism, which much of Enlightenment philosophy has questioned. The key ethical goal which economics has aspired to since Smith is the ideal of the 'wealth of nations', or 'public good' as Mandeville put this. Contemporary institutional and constitutional economics specified this with a view to a mutual gains program. For instance, in constitutional economics, we find the idea that an economic-ethical understanding of democracy rests on the idea that mutual gains are generated through rule changes to political organisation ${ }^{59}$. This is the way successful, democratic (in economic speak, 'pareto-superior') rule change is conceptualised.

${ }^{53}$ Oliver E. Williamson, The Economic Institutions of Capitalism (New York: Free Press, 1985), 29, 33-34, 76.

${ }^{54}$ Wagner-Tsukamoto, "Economics of Genesis", 264; Wagner-Tsukamoto, God an Economist?, 55-57; Wagner-Tsukamoto, "Paradise Story", 158-159; Wagner-Tsukamoto , "Slave Contract", 293-294; Wagner-Tsukamoto, "Tree of Life", 108, 110-111; Wagner-Tsukamoto, "After the Theft", 715-717, 729-739; Wagner-Tsukamoto, Economics of Paradise.

${ }^{55}$ Wagner-Tsukamoto, "Economics of Genesis", 275-277; Wagner-Tsukamoto, God an Economist?, 94, 96; Wagner-Tsukamoto, "Slave Contract", 297-298; Wagner-Tsukamoto, "Weber Thesis", 4; Wagner-Tsukamoto, "Homo Economicus in Jacob Stories", 86-87, 89-92.

${ }^{56}$ Wagner-Tsukamoto, "Exodus", 120-124; Wagner-Tsukamoto, God an Economist?, 123128; Wagner-Tsukamoto, "Slave Contract", 302-303; Wagner-Tsukamoto, "Weber Thesis", 5; Wagner-Tsukamoto, "Cooperation in Joseph Stories", 8, 16-30, 37-38.

${ }^{57}$ Wagner-Tsukamoto, "Exodus", 126-127; Wagner-Tsukamoto, God an Economist?, 150154; Wagner-Tsukamoto, "Cooperation in Joseph Stories", 36; Wagner-Tsukamoto, "State Formation", 399-401.

${ }^{58}$ Wagner-Tsukamoto, God an Economist?, 97, 189-194; Wagner-Tsukamoto, "State Formation", 402-428.

59 James M. Buchanan and Gordon Tullock, The Calculus of Consent: Logical Foundations of Constitutional Democracy (Ann Arbor, MI: University of Michigan Press, 1961); Buchanan, Economics Predictive Science; Buchanan, Ethics of Constitutional Order; Victor J. Vanberg, "James M. Buchanan's Contractarianism and Modern Liberalism," Constitutional Political Economy 25 (2014): 18-38. 
Conversely, unsuccessful rule change yields the economically unethical ('pareto-inferior') outcome of mutual loss. Can we trace this vision of mutual gains (and mutual loss) in the biblical text: Did successful (or unsuccessful) change of economic institutions yield mutual gains (or mutual loss)?

Mutual gains outcomes are visible in the conclusion of the Jacob stories ${ }^{60}$, in the Joseph stories ${ }^{61}$; to a much lesser degree in the exodus stories and Joshua stories ${ }^{62}$; but more widely so in the David stories and Solomon stories ${ }^{63}$. Mutual loss outcomes, mirroring the prisoner's dilemma predicament can be found in the Paradise story ${ }^{64}$, at certain points of the Jacob stories ${ }^{65}$, the exodus stories ${ }^{66}$, and in some of the settlement stories, including the Rehoboam stories ${ }^{67}$.

Moving on to the first heuristic element which I trace through economic reconstruction is the homo economicus; a model of rational, self-interested choice that optimises utility gains in one way or another (either through a strict 'maximisation' calculus or through a behaviourally set out 'satisficing' calculus). The idea of self-interested choice is the focal point of reconstruction. I investigated this idea in previous research on the Paradise story, for all actors involved, for God, Adam and Eve, and the serpent ${ }^{68}$; for Jacob,

${ }^{60}$ Wagner-Tsukamoto, God an Economist?, 88-89, 92-93; Wagner-Tsukamoto, "Slave Contract", 293, 298; Wagner-Tsukamoto, "Weber Thesis", 4; Wagner-Tsukamoto, "Homo Economicus in Jacob Stories", 90-92.

${ }^{61}$ Wagner-Tsukamoto, "Exodus", 126-127; Wagner-Tsukamoto, God an Economist?, 98, 121, 130-135; Wagner-Tsukamoto, "Slave Contract", 289, 301-304; Wagner-Tsukamoto, "Weber Thesis", 5; Wagner-Tsukamoto, "Cooperation in Joseph Stories", 15, 20-21, 32, 35.

62 Wagner-Tsukamoto, God an Economist?, 182-183, 196; Wagner-Tsukamoto, "State Formation", 402, 405.

${ }^{63}$ Wagner-Tsukamoto, God an Economist?, 188, 200, 235; Wagner-Tsukamoto, "State Formation", 411-412, 414, 416-417, 419.

64 Wagner-Tsukamoto, "Economics of Genesis", 269-270; Wagner-Tsukamoto, God an Economist?, 54, 58-60; Wagner-Tsukamoto, "Paradise Story", 160, 161-164; Wagner-Tsukamoto, "Slave Contract", 294; Wagner-Tsukamoto, "After the Theft", 712, 725-726, 732; WagnerTsukamoto, Economics of Paradise, especially chapter 5.

65 Wagner-Tsukamoto, God an Economist?, 87-90; Wagner-Tsukamoto, "Slave Contract", 297; Wagner-Tsukamoto, "Homo Economicus in Jacob Stories", 90, 94.

${ }^{66}$ Wagner-Tsukamoto, "Exodus", 119, 121-125; Wagner-Tsukamoto, God an Economist?, 154-157; Wagner-Tsukamoto, "Slave Contract", 304.

${ }^{67}$ Wagner-Tsukamoto, God an Economist?, 196; Wagner-Tsukamoto, "State Formation", 417-418.

${ }^{68}$ Wagner-Tsukamoto, "Economics of Genesis", 270-271; Wagner-Tsukamoto, God an Economist?, 63-70; Wagner-Tsukamoto, "Paradise Story", 149, 154-159, 162-167; WagnerTsukamoto, "Slave Contract", 293-295; Wagner-Tsukamoto, "Tree of Life", 104, 108-122; WagnerTsukamoto, "After the Theft", 706-707, 715-734; Wagner-Tsukamoto, Economics of Paradise, especially chapter 3 . 
Laban, and God in the Jacob stories ${ }^{69}$; for Joseph and the pharaoh in the Joseph stories ${ }^{70}$; for Moses, the pharaoh, and God in the exodus stories ${ }^{71}$; for Moses and the Levites in the stories of the exodus journey to the Promised Land ${ }^{72}$; and for the main actors involved in the settlement stories, Joshua, Saul, David, Solomon, and Rehoboam, and God's changing involvement in these stories ${ }^{73}$.

The identification of a model of rational, self-interested choice in biblical stories raises fundamental questions. I am not arguing here in any anthropological or psychological tradition, which would see the portrayal of human nature in an empirical, behavioural sense at stake when we meet the homo economicus in Old Testament stories. Rather, I argue for heuristic, methodological reasons that link a model of self-interest to an integral, undergirding theory building function: This model is 'merely' applied in order to see how economic institutions fare regarding the organisation of capital exchange for generating mutual gains. 'Even so' - or to be more precise, 'particularly so', when encountering the homo economicus - successful institutional and constitutional economic ordering is expected to yield mutual gains outcomes for the interacting group ${ }^{74}$.

A complementary, heuristic element of institutional economic analysis is the idea of a dilemma structure; in Buchanan's terms: homo economici are caught up in the 'Hobbesian jungle ${ }^{\prime 75}$. The prisoner's dilemma concept is an abstract illustration of this jungle, in which homo economici are interacting and end up with the worst possible outcome for the interacting group as a whole - on grounds of rational, self-interested choice. Mutual loss results. Institutional economics takes this outcome not in order to behaviourally critique or even to give up the model of the homo economicus or the idea of the Hobbesian war. Rather, it inquires how through situational intervention with economic institutions capital exchange and trade amongst interacting agents can be organised differently; to the mutual advantage of interacting parties. Like the homo economicus, the idea of the dilemma

${ }^{69}$ Wagner-Tsukamoto, "Economics of Genesis", 275-276; Wagner-Tsukamoto, God an Economist?, 110, 115-118; Wagner-Tsukamoto, "Slave Contract", 296-300, 305; WagnerTsukamoto, "Weber Thesis", 4; Wagner-Tsukamoto, "Homo Economicus in Jacob Stories", 85-93; Wagner-Tsukamoto, "City Metaphor", 16.

70 Wagner-Tsukamoto, "Exodus", 127; Wagner-Tsukamoto, God an Economist?, 133; Wagner-Tsukamoto, "Slave Contract", 301, 305; Wagner-Tsukamoto, "Weber Thesis", 5-6; WagnerTsukamoto, "City Metaphor", 23.

${ }^{71}$ Wagner-Tsukamoto, "Exodus", 123-125; Wagner-Tsukamoto, God an Economist?, 157165; Wagner-Tsukamoto, "Slave Contract", 303.

72 Wagner-Tsukamoto, God an Economist?, 171-173; Wagner-Tsukamoto, "State Formation", 399-400.

${ }^{73}$ Wagner-Tsukamoto, God an Economist?, 197-198; Wagner-Tsukamoto, "State Formation", 402-418.

74 James M. Buchanan, "The Constitution of Economic Policy," American Economic Review 77 (1987): 243-50; Homann, "Sinn und Grenze"; Wagner-Tsukamoto, Human Nature and Organization Theory: On the Institutional Economic Approach (Cheltenham, UK: Edward Elgar, 2003); Wagner-Tsukamoto, "Homo Economicus in Jacob Stories".

${ }^{75}$ Buchanan, Limits of Liberty. 
structure is therefore an essential heuristic tool of economic analysis. This understanding of the dilemma structure can be comprehensively reconstructed for many Old Testament stories, not only for stories in which we see interactions actually escalate and agents getting caught up in a mutual loss dilemma, but also for stories in which the dilemma was resolved to the mutual advantage of interacting agents. For both identifications, economic institutions are examined regarding a capability of unsuccessfully or successfully aligning interactions over capital exchange with a view to mutual gains outcomes.

Escalating dilemmas, which resemble the Hobbesian war and the prisoner's dilemma predicament, can be found in the Paradise story ${ }^{76}$; in the Jacob stories ${ }^{77}$; in the exodus stories $^{78}$; in the early settlement stories ${ }^{79}$; or in the stories after Solomon's reign ${ }^{80}$.

Resolved dilemmas with mutual gains outcomes can also be found, especially so in the Joseph stories ${ }^{81}$ and in the Solomon stories ${ }^{82}$. Through institutional economic reconstruction, the resolution of dilemmas in these stories is not attributed to the proverbial or divine wisdom of Joseph or Solomon as such; instead, their success is economically rationalised with a view to organising economic institutions in such a way that gains from trade and costs endured for agents to produce these gains yielded, in their final outcome, profits for all (i.e. mutual gains). In this economic sense, a climax of Old Testament storytelling, in terms of successful economic ordering, can be identified for these stories; and a hero thesis for Joseph and Solomon is implied.

\section{Questioning the Dualism Thesis}

The identification of economic patterns in biblical thought - with a view to capital exchange, economic institutions, mutual gains, homo economicus, and dilemma structure substantively sets out a concept of rational religion. In contrast with Smith's expectations, this reconstruction of Old Testament-based religion was grounded not only in the biblical text but also in his economics. We can see modern economics as ethics emerge from the ancient text. On this ground, the dualistic conception of ancient ethics as being radically

${ }^{76}$ Wagner-Tsukamoto, "Economics of Genesis", 268-270; Wagner-Tsukamoto, God an Economist?, 54-56, 58-63; Wagner-Tsukamoto, "Paradise Story", 156, 159-161, 167; WagnerTsukamoto, "Slave Contract", 294-294, 304-305; Wagner-Tsukamoto, "After the Theft", 215-733; Wagner-Tsukamoto, Economics of Paradise, especially chapter 5.

77 Wagner-Tsukamoto, "Slave Contract", 296-298; Wagner-Tsukamoto, "Homo Economicus in Jacob Stories", 86-87, 95.

78 Wagner-Tsukamoto, "Exodus", 119-120, 123-125; Wagner-Tsukamoto, God an Economist?, 141-156, 161-165; Wagner-Tsukamoto, "Slave Contract", 303, 305.

${ }^{79}$ Wagner-Tsukamoto, "State Formation", 402-403, 406-408.

${ }^{80}$ Wagner-Tsukamoto, "State Formation", 418-419.

${ }^{81}$ Wagner-Tsukamoto, "Exodus", 127; Wagner-Tsukamoto, God an Economist?, 120, 129, 133, 137; Wagner-Tsukamoto, "Slave Contract", 303, 305; Wagner-Tsukamoto, "Cooperation in Joseph Stories", 13-15, 23, 34-37; Wagner-Tsukamoto, "City Metaphor", 31.

82 Wagner-Tsukamoto, God an Economist?, 196; Wagner-Tsukamoto, "State Formation", 418-419. 
different from modern ethics (in the Smithsonian tradition of the Scottish Enlightenment) is open to dispute.

This challenge to dualism gains all the more force by coupling the economic pattern thesis with the new unitary thesis. The new unitary thesis argues that (economic) science can give a unified and ethical conceptual structure to the Old Testament text, in this way rivalling the old unitary thesis as implied by Nietzsche's nihilism and the historicalredactional school of biblical analysis: that merely faith alone could conceptually unify and save the biblical text. The new unitary thesis implies that dualism is objected to through the economic pattern thesis on a comprehensive basis rather than on grounds of identifying isolated or insignificant economic, conceptual patterns in Old Testament stories.

In this sense, of succeeding, comprehensive reconstruction of economic concepts in the Old Testament text, I can answer calls to substantively address the question of religion, from the viewpoint of an economics of religion. And in this specific sense, I can affirmatively answer Brennan and Waterman's question as to whether economics and religion were (and are) different ${ }^{83}$. This confirms my rejection of the dualism thesis.

Where does this leave Enlightenment philosophy with the project of ethical rationalism, freed from (biblical) religion and unconnected to economics as systemic ethics? As I noted, even the Scottish Enlightenment, with Smith as leader, faces this critical question, especially so when Smith made his call for rational religion. Buchanan likewise faces this question ${ }^{84}$; when (a) not dating back constitutional economics to the biblical text (Wagner-Tsukamoto 2009a, 2010); and (b) splitting the 'moral precepts' approach, as he termed this approach, from constitutional economics. There appears to be at least one layer of the moral precepts approach (i.e. religion in our case) that is economized in nature.

From here we can also intervene and negotiate in the debate on modernity and secularisation. I engage this intervention in the next section when asking about the pervasive and persistent influence of religion in contemporary society.

\section{The Pervasiveness and Normative Relevance of Rational Religion}

Why does religion still play a prominent role in contemporary, supposedly modern, secularised society?

\section{North's and Williamson's Questions}

Williamson examined various 'levels' of institutional order ${ }^{85}$. At a top level, he placed religion; followed by institutional structures which more closely resemble constitutional order, as for instance approached in economic terms by Buchanan; followed by institutions at a post-constitutional plane, such as the hierarchical structures of the firm, with contractual structures of two-agent interactions in a market economy at the lowest level. In this connection, Williamson raised the important question, by picking up North's inquiry, as to how and why religion could have a persistent and pervasive influence in society over time, 'even' so in contemporary society:

${ }^{83}$ Brennan and Waterman, Economics and Religion; Brennan and Waterman, "Introduction"; Brennan and Waterman, "Summary".

${ }^{84}$ Buchanan, Limits of Liberty, 117.

${ }^{85}$ Williamson, "New Institutional Economics". 
Institutions at this level [the level of religion] change very slowly - on the order of centuries or millennia - whereupon Douglass North poses the query, 'What is it about informal [religious] constraints that gives them such a pervasive influence upon the long-run character of economies?' (1991, p. 111) North does not have an answer to that perplexing question, nor do 1.86

Williamson and North seemingly intersect here with other research that disputes the proposal that 'modern', contemporary society was secularised and freed from religious influence. Examples of such critical, mostly empirically-based research are Reventlow, lannaccone, Inglehart and Baker, Berlinerblau, or McCleary and Barro ${ }^{87}$. The question that emerges here asks how is religion able to exert a pervasive influence in society over time?

The answer I want to set out draws directly on the economic pattern thesis, the new unitary thesis, and my rejection of the dualism thesis. I diagnose for capitalist societies and the market-based economies they have set up step-by-step since biblical times a conceptual affinity and match with an economic ethics of religion: Because Old Testament-based thought can be seen to be economically patterned, the top level of institutional order religion (and a moral precepts approach more widely read) - can so easily instigate pervasive influence on the lower levels of capitalist institutional ordering. The top level is not aloof or unconnected in conceptual economic terms from the lower levels. Rather, the opposite appears to be the case. It is economised in its very essence. This influence on the lower levels works not only through transaction cost efficiencies which religion can yield in society but also, and primarily so in my argument, through the very nature and substance of religious thought: economised religion conceptually embeds the economics at lower levels of constitutional contract; organisational governance; contractual governance of principalagent relationships in trade exchanges; etc.

In consequence, I follow an economic approach to conceptualise a pervasive influence of religion over time, and step away from sociological and socio-psychological concepts per se, such as 'social inertia', 'symbolic value', 'the insularity of a society', 'the absolute, transcendental' nature of religion, etc., as Williamson or Gorini suggested this ${ }^{88}$; and Buchanan seemingly talked about in a similar vein, when referring to the 'moral precepts' approach, 'moral community' and 'moral order' ${ }^{89}$.

In the understanding I set out, moral community, moral order or 'moral rules of religion' 90 - the 'moral precepts' approach, as Buchanan also termed this ${ }^{91}$ - are not merely

${ }^{86}$ Williamson, “New Institutional Economics", 596; North, “Institutions," 111.

${ }^{87}$ Reventlow, Authority of Bible, 411; lannaccone, "Progress", 738, 743; lannaccone, "Introduction", 1466, 1468, 1471; Inglehart and Baker, "Mondernization"; Berlinerblau, Secular Bible; McCleary and Barro, "Religion"; see also Arnold J. Band, "The Beginnings of Modern Hebrew Literature: Perspectives on 'Modernity'," AJS (Association for Jewish Studies) Review 13(1/2) (1988): $1-26$.

${ }^{88}$ Williamson, "New Institutional Economics", 596-597; Oliver E. Williamson, "Calculativeness, Trust, and Economic Organization," Journal of Law and Economics 36(1/2) (1993), 476-477, 479; Gorini, "Secular Ethics", 34-35;

${ }^{89}$ Buchanan, Limits of Liberty, 117; Buchanan, Economics Predictive Science, 289-300.

${ }^{90}$ Anderson and Tollinson, "Morality", 
behavioural rules: In their very essence they reflect economic or economised rules. In consequence, I question that '... moral codes were at least partially self-enforcing and that religion served as a voluntary portion of this self-enforcement mechanism ${ }^{\prime 22}$. I would argue that they are neither voluntary nor self-enforcing as such; but they are concepts or rules, broadly conceived, that provide economic embeddedness (economic 'discipline', 'glue', 'drivers') that substantively guides institutional ordering and exchange behaviour in society at levels below the top level of religion. This also contests claims such as Polanyi's or Granovetter's on the non-economic embeddedness of economic institutions ${ }^{93}$. The main thesis is that economizing at the lower levels of capitalist institutional ordering (i.e. constitutional contract, post-constitutional contracting and hierarchical and market-based institutional ordering in all its economic permutations) already are delineated for capitalist societies by the economic conceptual nature and substance of Old Testament-based religion. At least since ancient biblical times, rational capitalist religion has been matched in this regard closely with the emergence and development of capitalist society.

As noted this thesis addresses Williamson's and North's inquiries into the role of religion with regard to lower, constitutional and institutional levels of societal ordering (below the top level of religion). In this regard, my thesis can also add new insights into debates such as Stuckrad's (2013: 9) or Kippenberg's (2008: 143) ${ }^{94}$, when discussing the issue why modern constitutions could successfully create a model for plural societies that entertained shared religious ideas. I reconstruct such sharing through the economic pattern thesis.

\section{The Weber Thesis and Rational Religion}

The Weber thesis on the protestant ethic of capitalism captures an important aspect of my argument on the pervasiveness of religion, but I circle the Weber thesis, searching for the capitalist, rational ethics of religion rather than the religious ethics of capitalism; as I would generalise the Weber thesis, by pointing at the fundamental foundational nature of economics as ethics for understanding biblical religion - which Weber merely tended to equate with 'traditionalism' 95 .

Weber correctly realised that Protestants rather than Catholics were the more successful businesspersons in a number of $17^{\text {th }}$ - and $18^{\text {th }}$-century countries ${ }^{96}$. Perhaps the

${ }^{91}$ Buchanan, Limits of Liberty, 117.

${ }^{92}$ Anderson, "Mr. Smith", 1075.

${ }^{93}$ Karl Polanyi, "The Economy as Instituted Process", in Trade and Markets in the Early Empires (ed. Karl Polanyi, Conrad W. Arensberg, and Harry W. Pearson; New York: Free Press, 1957): 243-270; Mark Granovetter, "Economic Action and Social Structure: The Problem of Embeddedness", American Journal of Sociology 91.3 (1985), 481-510.

${ }^{94}$ Stuckrad, "Secular Religion", 9; Hans G. Kippenberg, "Europe: Arena of Pluralization and Diversification of Religions", Journal of Religion in Europe 1 (2008): 133-55.

${ }^{95}$ Lutz Kaelber, "Rational Capitalism, Traditionalism, and Adventure Capitalism. New Research on the Weber Thesis," in The Protestant Ethic Turns 100. Essays on the Centenary of the Weber Thesis (ed. William H. Swatos and Lutz Kaelber; London: Paradigm Publishers, 2005): 139163; Wagner-Tsukamoto, "Weber Thesis".

${ }^{96}$ Weber, Protestant Ethic. 
main reason for this appears to be that the Reformation brought Protestant religion conceptually closer to the Old Testament ${ }^{97}$ and the kind of economic conceptual fabric it reflects; in a sense, it aligned the Protestant faith with Judaism (rather than cultivating a stronger affiliation with the New Testament, as Catholicism favoured). The 'spirit of capitalism' and the 'calling for making money', as Weber singled these ideas out for Protestantism ${ }^{98}$, are in this understanding not a new and unique phenomenon in the history of developing capitalist society ${ }^{99}$ : However, this same point was explicitly, widely and continuously asserted by Weber, specifically claiming that Judaism as a religion played no significant role in the onset of capitalism. Regardless of their achievements, Jewish entrepreneurs remained 'adventurer capitalists', 'pariah capitalists' and 'booty capitalists' in his theory ${ }^{100}$. In this respect, I revise and broaden the Weber thesis: through the economic pattern thesis, the 'new' unitary thesis, the thesis on the rejection of dualism between ancient ethics and modern, Smithsonian ethics, and the pervasiveness of religion thesis. As Weber observed:

In the long run, no religious-ethical conviction is capable of barring the way to the entry of capitalism, when it stands in full armour before the gate; but the fact that it is [now] able to leap over magical barriers does not prove that genuine capitalism could have originated in circumstances where magic played such a role [in ancient times]. ${ }^{101}$

The economic pattern thesis, the new unitary thesis, and the rejection of the dualism thesis combined set out 'capitalism's full armour'. But what shall we do with this finding that in ancient times and supposedly in ancient text too, this conceptual armour is already present and fully-formed, that much more than pure 'magic' delineates ancient religion, as Weber claimed of the latter?

When specifically analysing the Old Testament, Weber focused on a legalistic approach to the Ten Commandments and derivate legal codes, including usury laws, etc. Only on grounds of this rather limited, narrowly legalistic reconstruction of the Old Testament as Gesetzesreligion, Weber (1952, p. 343) could rightly claim:

Rational economic activity on the basis of the formal legality [Ten Commandments, usury laws, etc.] never could and never has been religiously valued in the manner characteristic of Puritanism [e.g. ascetic Protestantism of $17^{\text {th }}$ and $18^{\text {th }}$-century

${ }^{97}$ Werner Sombart, The Jews and Modern Capitalism (New York: Burt Franklin, 1913), 249251; Wagner-Tsukamoto, "Weber Thesis", 9.

${ }^{98}$ Weber, Protestant Ethic, 51, 72.

${ }^{99}$ See Wagner-Tsukamoto, God an Economist?, 245-248; Wagner-Tsukamoto, "Weber Thesis", 2-3, 6, 9, and the literature reviewed there.

${ }^{100}$ For instance, Weber, Protestant Ethic, 17, 111, 130, 244-245; Kaelber, "Rational Capitalism, Traditionalism, Adventure Capitalism", 141-143.

${ }^{101}$ Weber, Economic History, 276; see also Irving M. Zeitlin, Ancient Judaism. Biblical Criticism from Max Weber to the Present (Cambridge: Polity Press, 1984), who puts forward a similar argument. 
Europe]. ... It was prevented by the dualism of the economic ethic which stamped as adiaphorous [neither good nor bad] certain forms of behaviour toward the outsider which were strictly forbidden with respect to brothers in belief. This was decisive. It posed difficulties for Jewish ethical theorists. ${ }^{102}$

The kind of economic magic that I reconstructed for the Old Testament text, however, was available to both 'insider' and 'outsider' dealings of Jewish capitalists. This conceptual magic spans a much wider section of the Old Testament than merely a legalistic reading of the Decalogue, usury laws, etc. In this respect, I can clarify the conceptual problems which Jewish ethical theorists struggled with, as Weber identified these. Nevertheless, by narrowly following the legalistic lead of Jewish ethical theorists and the implied view that Judaism were merely a Gesetzesreligion, Weber's vision of an economics of religion had to remain incomplete and also remained parochial compared with the broader appeal of a concept of rational religion, read in institutional economic terms, that could be foundational for the entire Judaeo-Christian tradition throughout time (but with specific qualifications to be made, e.g. regarding how Protestantism or Catholicism draw differently on the Old Testament).

The paper studied this subject matter from two different vantage points, (a) by looking at Williamson's and North's inquiry regarding the pervasive influence of religion in supposedly secularised, modern society, and (b) by reviewing Weber's thesis on the supposition that religious ethics of capitalism appeared from the $17^{\text {th }}$ century onwards only. On this basis, I discussed reasons as to how and why religion could have had a pervasive and persistent influence in market-based, capitalist societies, at least since ancient times. In order to sketch out answers, I drew on the concept of rational religion, as I elaborated on this concept earlier through the economic pattern thesis, the new unitary thesis, and my rejection of the dualism thesis.

In this regard, the staging of economics as ethics on the biblical text is of key importance since this lends not only normative-practical economic relevance to Old Testament-based religion but also yields normative-ethical relevance for Old Testament based religion: aspiring to a mutual gains-program. Nevertheless, this is an aspirational goal, which in the textual world of the Old Testament was far from easy to achieve, as the Paradise story, the exodus stories, the settlement stories, or the Chaoskampf stories of the exile exemplarily illustrate. Throughout, the Old Testament here spins fine eschatological lines of inquiry, economic one so this paper argued, that fluctuate between hope for a better future and threatening apocalypse.

\section{Conclusions}

The Old Testament is not an insignificant text. It foundationally grounds the JudaeoChristian tradition, and Islam builds on it in various respects too. Through the constitutional and institutional economic reconstruction of biblical texts, the paper discussed a concept of rational religion on a platform of four theses: The economic pattern thesis; the new unitary thesis; (the rejection of) the dualism thesis; and the thesis of the pervasive influence of religion over time, at least since biblical times. Each thesis is on its own conceptually

${ }^{102}$ Weber, Ancient Judaism, 343. 
challenging, but taken together they set out a theory and research agenda for rational religion.

Drawing on the institutional and constitutional economic approach to conceptualizing rational religion, the paper answered Smith's call to rationalise and in a sense to modernise biblical religion. This project also addressed contemporary calls in the field of economics of religion to analyse what religion stands for in its very substance and nature. Answers were arrived at through analyzing biblical religion that builds on the Old Testament text and through drawing on Smithsonian economics as ethics. This also qualified Smith's expectation that rational religion needed to be freed from the Bible and that some kind of ethical rationalism would be needed to ethically ground it (rather than his very own economics). It also qualified more recent expectations that (biblical) religion and political economy were far apart, mirroring the dualistic conception of religion and political economy that was a key conceptual milestone for the Enlightenment ${ }^{103}$.

North and Thomas, or North and Weingast in their outlines of the institutional economic history of capitalism, traced (changes to) economic institutions as the key point of origin from which mutual gains programmes can materialise in societal perspective over time (for many Western societies) ${ }^{104}$. Conceptually, their historic economic argument can be transposed to the textual societies of the Old Testament, both those which were highly performing (e.g. in the Joseph stories and in the Solomon stories), and those which were lowly performing (e.g. in the exodus stories or the in the stories after the Solomonic reign). Reasons for high or low performance of societies, both in an empirical historic economic research programme, such as North's, and in a textual economic research programme, like the one predominantly pursued in the current paper, are approached in the same way: With a view to economic institutions that aligned or misaligned self-interests of interacting agents, with mutual gains outcomes at stake. Both the rise and fall of real and textual societies is explained in this manner through the same conceptual apparatus.

Nevertheless, there is room for cooperation between empirical (e.g. historic economic) and textual research that draws on constitutional and institutional economics. The way I set out and rejected the dualism thesis and then extended this argument to the thesis on the pervasiveness of religion begins to interconnect empirical, constitutional and institutional (historic) economic research with my, at least initially so, mainly textually focused research on the Old Testament: Once the economic pattern thesis is projected to North's or Williamson's inquiry on the institutional top level of religion ${ }^{105}$ or to a debate of the Weber thesis, my textual research gains empirical relevance in a more conventional understanding. At this point, there is scope for narratological textual methodology and empirical (e.g. historic economic) research methodology to meet. Religious beliefs, religious values, religious discipline, and religious rules and how these embed economic exchange in our societies can already be seen to be (a) economically patterned; (b) through the Old Testament. Rational religion, economically constructed through biblical text, already

${ }^{103}$ For instance, as reviewed by Buber, Pointing the Way; Reventlow, Authority of Bible; Reventlow, Epochen der Bibelauslegung.

${ }^{104}$ Douglas C. North and Robert P. Thomas, The Rise of the Western World. A New Economic History (Cambridge: Cambridge University Press, 1973); Douglas C. North and Barry R. Weingast, "Constitutions and Commitment: The Evolution of Institutions Governing Public Choice in Seventeenth-century England," The Journal of Economic History 49 (1989): 803-832.

${ }^{105}$ North, "Institutions," 111; Williamson, “New Institutional Economics”, 596. 
embeds constitutional and institutional economic ordering at lower levels. A concept of rational religion is in this understanding one key contributing factor that empirically explains, from the top institutional level, the rise and fall of societies. This proposition is open to empirical scrutiny. And from here we can fundamentally contest historic economic research on antiquity, which claimed that economic structures of antiquity were entirely different as compared with modern ones ${ }^{106}$. The Bible's journey through history and its spreading is thus examined for how the economic fabric of its texts impacted the societies in which the Bible was taken up.

As much as a concept of rational religion, and the institutional economic theory of Old Testament-based religion it informs, has implications for the rise and pervasiveness of the capitalist economic system, it can also hint at why other economic systems did not persist through time. What could we expect if a non-capitalist economic system intentionally tried to eliminate capitalist rational religion, as I reconstructed this, from its societal cultural frame of embeddedness? Assuming this project could succeed, we would see the top level of institutional ordering, at which rational religion locates, being severely disturbed and possibly even falling into some kind of vacuum. The demise of communism may here hold some clues, especially regarding its attempt to eradicate religion. It goes unquestioned that there are many reasons why communism over time faded away, but at least one of the contributing factors can be speculated to be that communism succeeded to severely curtail the institutional embeddedness of rational religion in society. Can we then align reasons for the collapse of communism with God's final punishment of communism: for communism having restrained or even eliminated religion? The significant thesis here is that the fall of economic systems, and the rather different constitutional-institutional order they tried to erect, is facilitated and possibly even accelerated if such systems intentionally aimed to demote rational, economically patterned religion from a normative frame of economic reference and embeddedness.

${ }^{106}$ For instance, Moses I. Finley, Studies in Ancient Society (London: Routledge and Kegan Paul, 1974); Moses I. Finley, The Ancient Economy (Berkeley, CA: University of California Press, 1999). 